\title{
Cultural Marketing of William III: A Religious Turn in Katharina Lescailje's Political Poetry
}

\section{Nina Geerdink}

To cite this article: Nina Geerdink (2010) Cultural Marketing of William III: A Religious Turn in Katharina Lescailje's Political Poetry, Dutch Crossing, 34:1, 25-41, DOI: 10.1179/030965610X12634710163105

To link to this article: https://doi.org/10.1179/030965610X12634710163105

曲 Published online: 18 Jul 2013.

Submit your article to this journal $\pi$

山 Article views: 33

Q View related articles $₫$ 


\title{
Cultural Marketing of William III: A Religious Turn in Katharina Lescailje's Political Poetry
}

\author{
Nina GeERDink \\ VU University Amsterdam, NL
}

William III (1650-1702) and his wife Mary II (1662-1695) have been praised extensively by Dutch poets. One gets the impression that the government of the King-Stadholder was widely appreciated in the Dutch Republic, while in fact his position was not uncontested and this image was partly constructed in laudatory poems. The laudations for William were univocal in their praise and particularly religious in tone. The example of the Amsterdam female poet Katharina Lescailje (1649-1711) highlights both aspects of the poetry about William and Mary. The resounding praise for William, as well as the religious tone in the poems written during the 1680 s, was in remarkable opposition to her earlier political poems, written in the $1670 \mathrm{~s}$. In this article Lescailje's political poems from the period $1672-1702$ are examined in order to explain both the ideological and religious shift in her work.

KEYWORDS Poetry, Hacks, Religious shift, William III, Katharina Lescailje

\section{Introduction $^{1}$}

In the most recent Dutch biography of William III, the argument is made that, from today's perspective, the Dutch Stadholder (I672-I702) and King of England, Scotland, and Ireland (I689-I702) holds little popular appeal. ${ }^{2}$ Yet during William's life, the opposite seems to have been the case. In the Dutch Republic, a great many poems were written about William III and his wife Mary. ${ }^{3}$ Two aspects of these poems are remarkable. Firstly, almost all of them were laudations. Most poets started writing in William's honour around the time when he became Stadholder in 1672. After William and Mary ascended to the throne of England, Scotland, and Ireland in I689, the number of laudatory poems increased even further and grew ever more intense in adulation. There were poems by well-known learned authors, such as the clergyman Johannes van Vollenhove (I63I-I708) and the younger doctor and preceptor of the Amsterdam Latin School David van Hoogstraten (I658-I724), but many laudations 
were also written by minor or unknown poets. ${ }^{4}$ Secondly, almost all poems written in praise of William and Mary were religious in tone. ${ }^{5}$ Before 1672 , political poetry had been less liberal with the use of religious arguments and figures. In this article, both the univocal praise for William and Mary in Dutch poetry as well as the dominant religious tone are discussed. As will become apparent, these aspects were connected.

Many of the panegyrists of William and Mary had shown themselves to be supporters of the De Witt brothers in the Year of Disaster (I672), named after the disastrous events which took place that year. Not only had the Dutch Republic been attacked from three different sides at the same time, by France, England, and the two German states of Münster and Cologne, but it had also witnessed the lynching and murder of the De Witt brothers. ${ }^{6}$ The events of 1672 had far-reaching consequences for the political situation in the Dutch Republic. After the death of Stadholder William II in I650, a number of cities and provinces, most notably Holland, had blocked the appointment of a new stadholder. Power had resided with the States and, from I653 onwards, increasingly with the Grand Pensionary, Johan de Witt. But the foreign attacks of 1672 had harmed the position of De Witt irreparably, not only leading to his own and his brother's death, but also to the replacement of his supporters in provincial and city government. Seized by panic following the death of the De Witt brothers, the Republic turned to former Stadholder William II's son. William III was appointed Stadholder that same year and became the self-acclaimed new leader of the Dutch Republic. By replacing most of his opponents, he was able to consolidate the stadholderate. During the I670s and I680s, he would increasingly strengthen his position, both within the Republic and outside. ${ }^{7}$ William III was to become the most powerful Stadholder the Republic had seen until then. ${ }^{8}$

However, the relationship between the city of Amsterdam and the powerful Stadholder was precarious.' De Witt's politics of 'True Freedom' had granted the province of Holland and its largest city, Amsterdam, a privileged and very powerful position. Although here too, city regents had been replaced in the autumn of 1672 , little had changed. The differences between the former and the new regents were small and Amsterdam remained suspicious towards the newly appointed Stadholder and keen to protect its own autonomy and power. Yet Amsterdam's poets, who had supported De Witt and Holland's cause in their poetry before I672, began to shift their praise towards the Stadholder following the Year of Disaster. Moreover, like their colleagues elsewhere, they continued to honour William in the second half of the I670s, even though his military actions were deemed no longer essential and opposition against him grew. There were few poets who opposed the new government, and even the well-known anti-Orangist poet Joachim Oudaen ended up writing a laudation for William. ${ }^{\text {Io }}$ The 'cultural marketing' of William III would sweep the country and, when it did, it was set in a religious framework. ${ }^{\text {II }}$

The religious tone in itself was not that remarkable: the entire discourse surrounding William's politics, in the Dutch Republic as well as in England, was religious in tone. Although many of William and Mary's actions were not especially religious in 
themselves, or at least not particularly Calvinist or even Protestant, ${ }^{\mathrm{I} 2}$ religious arguments, rhetoric, language, and imagery played an important role in the public debate about William III, and especially the Glorious Revolution. ${ }^{{ }^{3}}$ In recent studies, it has been suggested that the image of William as a 'Defender of the Faith' was partly constructed by the circle around him, to justify his military deeds. ${ }^{\mathrm{I}}{ }^{4}$ No research thus far, however, has focused specifically on poetry, but it seems likely that this justification was an important reason for the dominance of religion in Dutch poetry as well. Poetry was in some cases closely connected to the circle around William, and in many cases closely bound to English discourses. At the same time, however, the religious tone of many Dutch poems remains remarkable. Not all of the authors were engaged particularly with either Calvinism or Williamite politics and the religious discourse was often unique to their political poetry. One such author was Katharina Lescailje (I649-I7II).

Katharina Lescailje had been working in Amsterdam as a printer and a poet from the I660s onwards. She wrote her first political poems in the Year of Disaster. In and shortly after 1672 , she had written poems in which she defended the De Witt brothers; however, from the I680s onwards, praise for William III came to dominate her poems and her political poems became more and more religious in tone. Why did Lescailje turn to William in the end and how can this religious shift be explained in her specific case? The remainder of this article looks at Lescailje's political poems in order to answer these questions. In the conclusion, the broader premises will be readdressed, and the way in which Lescailje's poems may be connected to late seventeenth-century Dutch political poetry in general will be examined. We first need to look at Katharina Lescailje's life, career, and her position in the political and literary world of the last quarter of the seventeenth century, in order to examine the possible reasons for her praise of William.

\section{Katharina Lescailje (1649-1711) as a cultural marketer}

Political poetry was an interplay of motives, of ideology, commerce, and patronage. They did not exclude each other. In fact, these motives were often connected and reinforced each other. ${ }^{\mathrm{I5}}$ For the panegyrists of William III, many of whom had previously supported the De Witts, this was of course no different. Jonathan Israel has shown how, for radical republicans, 'supporting William III became the only logical position' ideologically, at least after $\mathrm{I} 688 .{ }^{\mathrm{I} 6}$ However, considering the scope of the cultural marketing of William III, which took over almost the whole of the literary landscape, even in Amsterdam, there must have been more pragmatic reasons for the laudations as well. De Vet has already given examples of this. He has shown how patronage must have been an important stimulus for many of the panegyrists. Some of them, such as Samuel Sylvius (I655-I723) and Dirck Buysero (I644-I708), were associated with the court through family relations: Sylvius worked in one of the Prince's palaces and Buysero's father was a registrar, councillor, and steward to William. Others, like the Amsterdam theatre director Joan Pluimer (I646-I720) and 
the Amsterdam playwright Lucas Rotgans (I653-I7IO), were rewarded by William with commemorative medals for their poems. They would show their gratitude in new poems. ${ }^{17}$ Lescailje never received such patronage from the Prince of Orange and, as far as we know, she was never honoured by him.

Katharina Lescailje was a well-known figure on the Amsterdam literary scene. ${ }^{\text {I8 }}$ She was the second daughter of the well-known publisher and poet Jacob Lescaille. Since he was the main publisher for stage plays and was well acquainted with many Amsterdam poets, it is likely that she had moved in artistic circles since early childhood. Since the I720s, the story went that Joost van den Vondel, the uncontested patriarch of Dutch poetry, had read several of her poems and had encouraged the II-year-old Katharina to become a poet. Whether this story was true or not, Lescailje did indeed become a poet. She wrote many poems, some of which were published. She also translated more than seven tragedies, six of which were performed at the city theatre and were also published. When her father died in I679, Katharina Lescailje took over the publishing house with her younger sister Aletta. They kept the publishing house closely tied to the theatre and Katharina was able to publish her own works. Her occasional poetry revealed how she moved in circles of the Amsterdam cultural elite: many of the poems she wrote were addressed to fellow writers - both men and women. Lescailje's collected works were published by her nephew in I73I, twenty years after her death of which the title page is reproduced as Figure I. $^{\text {I9 }}$

Two aspects of Lescailje's authorship must be considered as important to the analysis of the political attitude in her poems about William and Mary. In the first place, Lescailje was a woman working in a male-dominated world. She was the first woman in the Dutch Republic who consistently wrote and published political poems. In her more than twenty political poems, she scarcely reflected directly on her involvement in male genres. Instead, Lescailje appears to have quietly adopted most of the conventions upheld by the literary men in her environment. ${ }^{20}$ Secondly, Lescailje remained unmarried and had to earn her keep by writing and publishing, especially after the death of her father in I679. ${ }^{2 \mathrm{I}}$ It may, for example, have been no coincidence that she started writing political poems in the same year that the theatre - the most important client of the family publishing house - closed.

Lescailje's attitude in the political poems must have been influenced by both the fact that she had to maintain her reputation among the circles of male poets surrounding her and the fact that she had to ensure her own income. These two interests were interrelated because many of the Amsterdam male poets in her network also held powerful positions in the Amsterdam theatre, on which Lescailje's income as publisher was partly dependent. These positions changed over time and Lescailje had to deal with men with a diversity of interests. On the one hand, there were the playwrights of the theatre association Nil Volentibus Arduum ('nothing is difficult for the willing'). In some of their subversive plays and poems, these playwrights were critical of William III, although they did not highlight their criticism. ${ }^{22}$ In the I670s, Nil dominated the Amsterdam literary scene, and in the period I678-I68I the theatre's board was made up of members of the association. ${ }^{23}$ On the other hand, from 1688 onwards, the board consisted of Joan Pluimer and his associates, who showed 


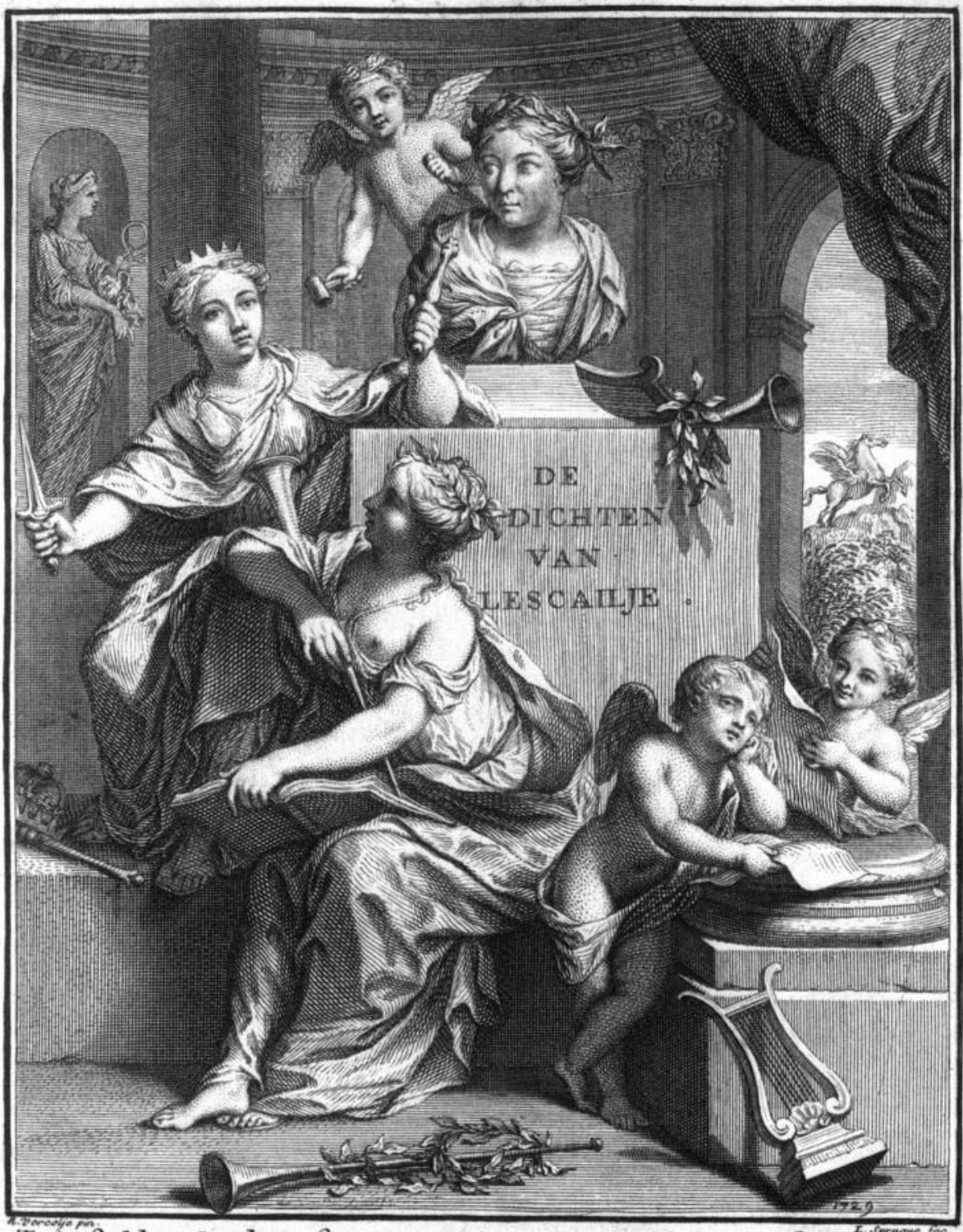

TeAmiteldam, by de Erfgen : yan J.Le scan, JE en D.RANK, op deBeursilus.

FIGURE 1 Title page from Katharina Lescailje, Toneel- en Mengelpoëzy (1731), vol. I. By permission of Universiteitsbibliotheek Utrecht.

themselves to be convinced Orangists. ${ }^{24}$ And as if these powerful men's opposing attitudes did not make her position difficult enough, Lescailje also needed to take account of the relationship between the city government and the Stadholder. Finally, her poems had to appeal to a wide readership, to ensure her income. Without even considering her own ideological viewpoint, it is clear that Lescailje's position with regard to her political poetry was complex. ${ }^{25}$ It is safe to assume that the religious 
shift in her political poems had something to do with this complexity. The poems she wrote between 1672 and 1702 demonstrate both the religious shift and the tensions brought about by the difficulties of her position.

\section{Poems on the Year of Disaster (1672)}

Immediately after the death of the De Witt brothers, those who condemned their brutal murder remained relatively quiet. There were few critical publications and these were published anonymously. ${ }^{26}$ This silence may have been influenced by the fact that, from I6 September onwards, anti-Orangist writings were suppressed; and from 27 September, all criticism of the government was banned. ${ }^{27}$

Lescailje wrote four poems that overtly supported the De Witts' cause. Two of them, short laudatory poems about Johan and Cornelis, were published in an anthology of 1676: Het Swart Toneel-gordyn, Opgeschoven voor de Heeren Gebroederen Cornelis en Joan de Wit (The Black Theatre Curtain, Opened for the Gentlemen Brothers Cornelis and Joan de Wit). ${ }^{28}$ The anthology gathered all kinds of poems that praised the De Witts and condemned their murder. It was published anonymously, but some of the poems were signed. It seems that the publication of these poems was no longer particularly dangerous, as a consequence of the increase in public criticism of William III following the Gelderland affair in $1675 .{ }^{29}$ Lescailje's poems, 'Op den Heer Mr Joan de Wit, Raadpensionaris van Holland, enz.' ('To Joan de Witt, Grand Pensionary of Holland, etc.') and 'Op den Heere Mr Cornelis de Wit, Burgermeester der Stad Dordrecht, Ruwaard van Putten, enz.' ('To Cornelis de Witt, Burgomaster of the City of Dordrecht, Regent of Putten, etc.'), were signed 'Kat. L.' This was probably obvious enough for most readers to recognize the Amsterdam poet and publisher. It is possible that these two poems were circulated before 1676, in manuscript or in clandestine and anonymous print, but it is also possible that they were only written in 1676 . Two more poems by Lescailje overtly supporting the De Witts have only survived in her collected works of I73I: 'De Verdrukte Vryheid aan Amsteldam' ('The Oppressed Freedom to Amsterdam') and 'Hollands Treurklacht' ('Holland's Elegiac Complaint'). ${ }^{30}$ It is uncertain whether these poems had been published before, but unlike the two poems published in Het Swart Toneel-gordyn, their topicality makes it almost certain that they were written in 1672 . These poems most likely were circulated in or immediately after 1672 , in manuscript or in clandestine and anonymous print.

In their recent literary history of the Dutch seventeenth century, Karel Porteman and Mieke Smits-Veldt suggest that Lescailje kept 'Holland's elegiac complaint' to herself because of the dangers of publishing a poem critical of William III. ${ }^{3 \mathrm{I}}$ Indeed, 'Holland's elegiac complaint' and the other poems about the events of I672 praised the De Witt brothers, and were sceptical of William's leadership. In a patriotic discourse the (former) political system of the Dutch Republic was praised in opposition to the monarchical system of its foreign enemies. The De Witt brothers were linked to the 'freedom' of the Dutch Republic, and William's ability to maintain this freedom was in fact doubted. The poem in honour of Johan de Witt, for example, characterized 
him as 'Hollands Steunpilaar' ('Holland's Pillar', 1. 2). He was compared to Cato and Cicero - two famous representatives of freedom ${ }^{32}$ - and he was said to have 'carried the honour of freedom' ('die de eer der Vryheid heeft gedraagen', 1. 6). In the two longer poems, freedom was personified and in 'The Oppressed Freedom to Amsterdam', Freedom spoke directly to the reader. Although the concrete meaning of 'freedom' in the poems referred to the independence of the Dutch Republic, Holland, or Amsterdam, from foreign tyranny, to contemporary readers this also would have had connotations of the 'true freedom' for which Johan de Witt and his supporters argued in their political ideology. ${ }^{33}$

In any case, the freedom in both of the longer poems related to Johan de Witt and his supporters - the Amsterdam burgomasters among them - rather than to the recently appointed Stadholder, William III, who had now become the defender of the Republic. In 'Holland's Elegiac Complaint', William was only mentioned after more than sixty lines of complaints about the loss of the De Witt brothers, who took freedom with them. He was called an 'onnooz'le Deugd' ('innocent Virtue', 1. 77). Personified Holland directly addressed him in her speech. She was critical of the defence of the Province. In early November I672, William had embarked on a military campaign in the South, which meant that the number of troops available for Holland's defence had decreased. Holland feared an attack by the French once the defence line of water had frozen. ${ }^{34}$ In the poem, Holland assumed that William had been advised by the wrong people and urged him to stop taking these 'gruwelpesten' ('gruesome plagues', 1. I06) seriously. Since it remains unclear what was meant by these 'gruesome plagues', this should be interpreted as a cover for the criticism of the new leader of the Republic. The suggestion that William had been ill-advised implied that he was not the one to blame. This type of explanation was a trope for criticism of the leaders. ${ }^{35}$

In the rest of 'Holland's Elegiac Complaint', as well as in the other poem from I672, 'The Oppressed Freedom to Amsterdam', William III was absent. His newly acquired stadholderate was not mentioned, nor was any opinion expressed on it. Instead, the poems emphasized the opposition between the monarchical, tyrannical government of the enemy and the more democratic government of the 'free' Dutch Republic. ${ }^{36}$ In the whole of the first part of 'Holland's Elegiac Complaint', Holland focused on her citizens. They were held responsible for the murder of the De Witt

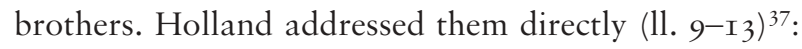

Myn onderdaan, gy waart verblind,

Toen gy die sterke steunpilaaren

Van wit albast, zo gantsch ontzind,

Myn troon ontrukte, ô onërvaaren

En misgeleide domme schaar!
My subjects, you were blinded, When you tore those strong pillars Of white alabaster, completely insane, From my throne, oh callow And deceived dumb crowd!

In the lines that follow, Holland argued that the subjects had failed to judge and act as they should have done. They were supposed to have acted in the interest of the commonwealth, but they had not. The murder of the De Witt brothers had brought Holland nothing but disaster. 'Holland's Elegiac Complaint' thus bestowed an 
important political obligation on Holland's citizens, which they had failed to meet. The responsibility of the citizens to aid their government was part of the patriotic discourse in the poem, since it emphasized the subjects' feelings of responsibility and unity. Together they had to defend the freedom of their province.

In the poem entitled 'The Oppressed Freedom to Amsterdam', personified Freedom appealed to Amsterdam in distress: if Amsterdam did not come to her aid, she would be lost for ever. The topicality of the poem is the same as in 'Holland's Elegiac Complaint': William's military campaign in the South had caused panic about a possible attack from the French across the frozen defence line of water, in the late autumn of I672. Both poems argued for a better defence of the province. In her plea in 'The Oppressed Freedom to Amsterdam', Freedom emphasized the reputation of Amsterdam as the 'city of freedom'. She mentioned the absence of 'hoofsche slaaverny' ('courtly enslavement', 1.6) in the city, referring to the absence of foreign tyrants, but at the same time voicing strong criticism of any form of monarchical government and emphasizing the autonomy of Amsterdam. Other elements of the patriotic discourse were the references to the Dutch Revolt and its struggle for freedom, and the use of the word burgervaders. The conventional term for mayor, it literally means 'citizens' father' and is therefore meaningful, in this context, in its emphasis on the non-tyrannical role of these rulers. At the end of the poem, the burgervaders were encouraged explicitly to keep fighting for Freedom. A comparison of the mayors of Amsterdam with the Roman Cato and Brutus, in the last lines, functioned as a reinforcement of the emphasis on the patriotic role of the burgomasters, since Brutus, like Cato and Cicero, was a famous symbol in patriotic literature. ${ }^{38}$

The patriotic discourse, with its references to the Revolt and the 'freedom' of the Dutch Republic, became emphatically bound to Holland and Amsterdam, and to a certain extent De Witt's cause features in Lescailje's poems from I672 onwards. Although she did not criticize William explicitly, the tone of her poems could not have been any clearer: the poems defended the De Witt brothers, condemned their murder, and showed little confidence in the leadership of William III. The poems in fact portrayed fear for the loss of the former freedom and autonomy of the powerful Province of Holland and city of Amsterdam, both because of the foreign attacks and because of the newly won power by William III. This was even the case in the only poem Lescailje wrote in praise of William III during the Year of Disaster.

Some days before the murder of the De Witt brothers, William had visited Amsterdam and Lescailje had written a poem on the occasion of his departure on I5 August 1672: 'Op het Vertrek van den Doorluchtigsten Vorst zyn Hoogheid Wilhem den Derden, Prince van Oranje, Grave van Nassouw, enz: Stadhouder, Kapiteyn en Admiraal Generaal der Vereenigde Nederlanden, enz.' ('On the Departure of the Most Serene Highness William III, Prince of Orange, Count of Nassau, etc.: Stadholder, Captain and Admiral General of the United Netherlands'). ${ }^{39}$ The poem was published as a pamphlet and presented the adulation of William III within the same patriotic discourse as in the later poems, which were critical of him or ignored him altogether. The poem must have pleased a wide audience at the time of the riots against the town 
governments. Yet the poem not only praised William, it also praised the government of the city of Amsterdam. The poem's argument focused entirely on Amsterdam, which was personified and spoke to William. She asked him to protect the city against foreign attacks, to enable the Amsterdam burgomasters to do their job and to take care of politics within the city wall as they had done before. The tension between the adulation of William on the one hand, and Amsterdam on the other hand, affected the poem's balance, but the patriotic discourse, applied to both, largely made up for this.

\section{Victory and peace (1673-1678)}

In the winter that followed the Year of Disaster, the tide turned for the Dutch Republic. Lescailje's poems of 1673 maintained the patriotic discourse, but by this time the political situation had changed completely. The advance of the foreign forces into Dutch lands was finally stopped. In June I673, the combined French and English naval forces attacked the Dutch Republic at sea. This appeared to be more difficult than expected: three times the small Dutch fleet, commanded by Michiel de Ruijter, managed to defeat the enormous fleet of the enemies. The euphoria over these victories was directed towards William III. The sudden reversal of Dutch fortunes was attributed to his leadership, and even supporters of the De Witt brothers now accepted him as their new leader. This was not the case, however, in the poems Lescailje wrote in reaction to the naval battles. Although they were not explicitly critical of William III, the euphoria about his leadership was absent. Lescailje praised only Michiel de Ruijter and the other naval commanders, and again paid much attention to the Dutch citizens within a framework of references to patriotic sentiments.

In 'Hollants Zege ter Zee' ('Holland's Victory at Sea'), written in honour of the first two naval battles in the waters of Zeeland in 1673 and published that same year as a pamphlet, William III is mentioned only once and alongside Michiel de Ruijter, his loyal right-hand man..$^{\circ}$ It was meant as a reassurance. Indeed, it gave some hope for the future, but the citizens were warned not to take their freedom for granted. The poem suggested that freedom had been regenerated with the help of God and urged them to protect it for the future ('Holland's Victory at Sea', ll. IOI-III):

En gy, myn trouwe Landgenooten,

Bewyst dus dat gy uit het zaad

Der Batavieren zyt gesprooten;

En toont het altyd met de daad,

Dat ge eerder 't levenslicht wilt derven

Dan Godsdienst, Vryheid, Vaderland,

En 't eeuwig graf van eer verwerven,

Dan lyden dat men laf $u$ spant

In 't uitheemsch juk van dwinglandyë:

Want immers zyt gy te êl van bloed,

Uw vryheid past geen slavernyë.
And You, my loyal Compatriots.

Prove now that You are of

Batavian seed;

And show always with an act, that

You would rather lose the light of life

And gain Religion, Freedom, Fatherland,

And the eternal Grave of honour,

Than experience cowardly enslavement

In the foreign yoke of Tyranny:

Because, after all, You are born too noble,

Your Freedom does not fit enslavement. 
Again, the poet warned the citizens of their responsibilities towards the country, using similar references to those in the poems from the year before. There was the implicit suggestion that the Dutch Republic and 'freedom' were inseparable and comparisons were made with the Batavians - both had been lodged in the Republic's collective memory ever since the Revolt. Moreover, the foreign yoke ('uitheemsch juk', 1. I09) was pointedly monarchical. In the rest of the poem the enemies, France and England, were explicitly referred to as being monarchies. The ships of the enemies were called 'Koningklyk' ('royal', 1. I4) and 'Koningskielen' ('royal vessels', 1. 27) - whereas the Dutch ships were linked to De Ruijter — and the defeat of the 'big Kingdoms' by little Holland (1l. 85-87) was emphasized. This, of course, did not mean that the poem was necessarily anti-monarchical, but it certainly emphasized the difference between the Dutch Republic and England and France, whose monarchs were regarded as tyrants.

In 'Holland's Victory at Sea' the patriotic discourse was thus continued, without taking an explicit stance in favour of or against the position that William III had acquired for himself. There were three elements within the patriotic discourse which enabled Lescailje to avoid an explicit position: the contrast between the triumphant Holland and the enemy monarchies; the references to the past of the 'free' Dutch Republic; and the emphasis of the rights and duties of the citizens. Taking an explicit position in support of William III, at the time of the victory, would have harmed both Lescailje's reputation with the Amsterdam governmental and cultural networks and her credibility with her readers. Yet actively participating in the collective euphoria was, of course, lucrative, and a critical stance against the most powerful man in the Republic would have been harmful. Lescailje's position was thus complicated, and it would only become more so while William III continued to consolidate his position during 1673 .

The poems Lescailje wrote at the end of 1673 , on the occasion of the withdrawal of the French, bear witness to these problems. On the one hand, there was a poem in which Lescailje celebrated the French withdrawal from the city and Province of Utrecht as a victory of God, on the other hand there was another in which she welcomed William III on behalf of the town of Woerden as the protagonist of the same victory. ${ }^{4 \mathrm{I}}$ In this poem on William III, 'Woerdens Wellekomst aan zyn Koningklyke Hoogheid, den here Prince van Oranje, Langgewenschten Stadhouder, en Kapitein Generaal der Vereenigde Nederlanden' ('The Welcome of Woerden to his Royal Highness, the Prince of Orange, Long Desired Stadholder, and Captain General of the United Netherlands'), written in November 1673, the patriotic discourse applied to the newly appointed Stadholder. The occasion of the poem was the arrival of William and the army of the Republic in the Province of Utrecht after the withdrawal of the French troops. In the poem, William was represented as the aide of the country and its inhabitants in defending its freedom against France, England, and the German States. Personified Woerden told William that her citizens were content and that every 'Batavian', from now on, was prepared to fight for peace ('The Welcome of Woerden', 11. I8-I9, 29-32): 
Geen Batavier wil 't sterflot myden, Als by met $u$ [William] om Vreê mag stryden

(...)

Hoe zou dan niet myn Burgeryë

Zyn uitgelaaten van de vreugd,

Op 't zien van uwe heldendeugd,

Die haar verloste uit slaavernyë:
No Batavian wants to avoid the fate of dying

If he is allowed to strive with you for

peace.

(...)

How could my Citizenship not be

Exalted with joy,

As they see your heroic goodness,

Which has freed her from slavery:

Within the patriotic discourse, it was emphasized how William, leader of the 'free' Dutch Republic, defeated the glory of a monarch (1. Io), Louis XIV of France. At the same time, however, William was said to have acquired 'Koningklyke glansen' ('royal lustre', 1. 35) himself. In the title of the poem he is even referred to as 'his royal highness', although at the time he was not yet King. ${ }^{42}$ There appeared to have been a tension between the powerful, almost monarchical position of William, which formed a risk for the powerful and autonomous positions of the Province of Holland and the city of Amsterdam, and the patriotic discourse in which the freedom of the Dutch Republic and all its provinces and cities dominated.

At the end of 1673 , William's main role was that of commander of the army and hammer of the foreign tyrants. He was the hero of the Dutch Republic and as such he was praised in Lescailje's poems — although ambiguously — within a similar patriotic discourse that dominated her earlier poems, which had focused only on Holland's and Amsterdam's interests and which had been critical of William. As the situation in the Republic settled down from I673 onwards, William continued fighting other countries. This caused disagreements with Amsterdam and Holland. The panic of the Year of Disaster had disappeared and as the situation in the Dutch Republic improved, William's position deteriorated. ${ }^{43}$ In her poems on the occasions of peace in 1674 and 1678 , Lescailje continued her patriotic discourse, ignoring William III almost completely. ${ }^{44}$ Instead of him, she praised the heroes of the army, the Amsterdam city regents, and God.

\section{Praising William III (1688-1702)}

When William became King of England, Scotland, and Ireland in I689, Lescailje began to write poems exclusively about William, as the leader of the Dutch Republic and of England. Although his position in the Republic deteriorated only further, her praise - and that of the other poets, for that matter - actually became more univocal and resounding. The market for poems in praise of William III was substantial. ${ }^{45}$ Apparently, Lescailje felt it necessary to take part in this cultural marketing of William, too. By then she had to earn her own living, mainly through publishing poetry, since the number of plays published by her and her sister had decreased since I687. ${ }^{46}$ Moreover, she still needed to secure her position in the world of male poets, which was now dominated by Orangist writers like Joan Pluimer.

Lescailje did not miss any of the deeds of William and Mary which led to general euphoria in the Republic, although it is uncertain whether all of her poems were 
published. It all started with William's departure for England in I688. On this occasion, Lescailje wrote the poem 'Op den Heere Prinse van Oranje; Triomfeerende in Engeland' ('To the Lord Prince of Orange; Triumphant in England'). ${ }^{47}$ Many poems praising William's crossing were published in pamphlets, but Lescailje's poem has not survived in any of them. ${ }^{8}$ The same was true of her poem on the occasion of William's first return in I69I, 'Op de landing van Koning Wilhem' ('On the Landing of King William'). ${ }^{49}$ When William returned to the Dutch Republic for the first time, he was celebrated all over the country, but especially in The Hague, where he was welcomed with triumphal arches. There was a great deal of activity, also in literary circles. Many poets praised the Stadholder and Lescailje was one of them..$^{\circ}$

Less cheerful occasions only a few years later had even more impact. The demise of both Mary II (I695, N.S.) and William III (I702) were the subject of many poems. Lescailje wrote an elegy on both occasions. Her elegy for Mary, 'Rouwklagt over de Dood van de Koninginne van Groot Brittanje' ('Elegy on the Death of the Queen of Great Britain') was published twice, once in its own right and for a second time in the collection Opkomst, Geboorte, Leven en Dood van Maria Stuart, Koninginne van Groot-Brittanien, Vrankryk en Yerland (Rise, Birth, Life and Death of Mary Stuart, Queen of Great Britain, France and Ireland). ${ }^{51}$ The elegy for William, 'Aan Nederland; op de Dood van Zyne Majesteit' ('To the Dutch Republic; on the Death of his Majesty'), again, has not survived in published form other than in the collected works of I73I. ${ }^{52}$ The patriotic discourse had disappeared in the four poems Lescailje wrote in praise of William and Mary from I688 onwards. Lescailje did not present William III as a ruler leading the country together with and in the service of the citizens, but instead as having led the country together with and in the service of God. The following example from the poem she wrote on the occasion of William's return to the Dutch Republic in I69I, after defeating James II and becoming King of England, Scotland and Ireland, is telling. The first stanza described the terrible weather in which William had made his crossing. He arrived safely, however, and the second stanza explained why God had kept him safe (11. 5-8):

God, zyner Vaad'ren God, draagt zyn Gezalfde op handen

Voor welkers heilige eer hy 't zwaard zwaait, vol van moed;

En voor Beschermer des Geloofs alöm begroet,

Legt hy het Ongeloof en Dwing'landy in banden.

God, the God of his Fathers, carries the Anointed on his hands

For whose holy honour he draws the sword, full of courage;

And he, who is regarded by everyone as the Defender of the Faith,

Is restraining Unbelief and Tyranny.

William was God's 'Anointed'. More than as a champion of freedom, he was presented as a champion of religion. In the poem written on the occasion of his departure, three years earlier, he was portrayed in the same way, although 'the people' were also present in this poem. Lescailje described William's mission as going to plant 'Vryheid en Geloof' ('Freedom and Religion', 1. 7) in England, and protecting the 
rights of 'God en 't Volk' ('God and the People', 1. 8). This referred of course to William's actions against the Catholic James II and VII, who, in Calvinist public opinion, kept his people in subjection - a direct result of his Catholicism. Moreover, the poem's seeming patriotism was lessened when the guiding force behind these great deeds was uncovered. This was not William himself, but the Light of God, in whose service William left for Great Britain and would succeed. The responsibility of the people of Britain was not mentioned: they would be governed by God, through William. The heavenly ruler thus outshone the earthly ruler. Lescailje had used a similar approach before, in the poems on victory and peace. When William III was absent from the poems, it was often God who was praised and thanked instead of him.

The former patriotic discourse had now disappeared, and a religious discourse had taken its place. ${ }^{53}$ This shift should be connected to both Lescailje's and William's position. Commercial and literary interests had forced Lescailje to praise William, although his deeds did not seem to inspire adulation. Although William III presented himself as a champion of freedom, the ongoing unpopular wars and the problems between Amsterdam and William made it impossible for Lescailje to continue to write within the patriotic discourse. ${ }^{54}$ The religious discourse, however, could bridge the ostensible opposition between the resounding poetic adulation and the reality of William's actions. This is confirmed by the poems Lescailje wrote in the same period in honour of Amsterdam burgomasters. In these poems the patriotic discourse was maintained. ${ }^{55}$ The discourse had only changed in her poems on the Stadholder.

\section{2: 'Blessing of War' ('Oorlogszege')}

Shortly after William's death, Lescailje wrote the poem 'Oorlogszege' ('Blessing of War'). ${ }^{56}$ It was written in May 1702, shortly after the outbreak of the War of the Spanish Succession (I7OI-I7I4). Both William and Amsterdam had argued in favour of this war, but for different reasons. ${ }^{57}$ For William, the war would have been part of his permanent campaign against the expansion of France, whereas for Amsterdam, the overriding reasons were commercial. The poem did not favour either argument. Instead, it rejoiced over the war because it was right that the Republic was fighting for freedom again. The earlier battle for freedom was recalled and the patriotic discourse thus appeared to be 'back'. Still, the religious discourse had not disappeared completely. It was apparently maintained to justify the fact that the poem expressed joy over the war, rather than mourned William's death. The religious discourse dominated the second part of the poem, which suggested that the loss of William, including as a leader in this war, was God's will: 'op dat ge alöm door Hem zoud zegepraalen' ('as to make you [the people] triumph completely because of Him', 1. I4). All credit was now due to God and the people could be governed by him directly; William III was of no use anymore as deliverer. Indeed, in poems written two years later on the occasion of the victory at Blenheim, Lescailje thanked God in the first place, alongside the heroes of the battle. ${ }^{5}$ 


\section{Conclusion}

In the poem from I702, the religious discourse justified the absence of praise for the recently deceased William III, whereas in the earlier poems the religious discourse provided justification for his praise. In both cases, the discourse supported Lescailje's authorship. The cultural marketing of William III was part of her commercial and literary agenda. Regardless of her own ideas on politics, the contribution of her poems to the consolidation of a political cause depended on what was most profitable for both her earnings and her literary reputation at the time. Her position was complicated by the opposing interests of those on which her success depended, causing tensions in her political poetry. Her earliest poems, written around 1672, mainly supported the De Witts and were critical of William III. She wrote within a patriotic discourse, focusing on the freedom and autonomy of Amsterdam and Holland. In the period I673-1678 the problems of Lescailje's position became most obvious: there was some praise for William as a military commander, within the same patriotic discourse, but her heart was apparently not in it and her praise was rather ambiguous. Only after William III went to England in I688, did she really turn into one of his cultural marketers. A new religious discourse, instead of the former patriotic discourse, accompanied the shift.

The sudden appearance of a religious discourse in Dutch poetry was linked not only to William's self-representation, but also to that of the poets. By justifying William's actions, the religious discourse justified the abundant adulation of the Stadholder at the same time. At least, this seems to have been the case with Lescailje. For other poets as well, the religious discourse, inspired by William and his supporters, may have worked well to legitimize their pragmatic reasons for his praise. It would be interesting to examine other poets' works from this period, to see whether, in their poetry, a religious discourse also replaced a patriotic one. The poets' need for justification may then have been a reason for the dominance of religion in the discourse on William and Mary.

\section{Notes}

I I would like to thank Jan Hartman, Ton van Strien, and the anonymous reviewer for their comments on earlier versions of this article.

2 W. Troost, Stadhouder-koning Willem III. Een Politieke Biografie (Hilversum: Verloren, 200I), p. 9 .

3 See for example the recent literary history by K. Porteman and M. B. Smits-Veldt, Een Nieuw Vaderland voor de Muzen. Geschiedenis van de Nederlandse literatuur I560-I700 (Amsterdam: Prometheus/Bert Bakker, 2008), pp. 787, 795. For an idea of the numbers one only needs to look into the relevant years in the pamphlet catalogue by Knuttel, W. P. C. Knuttel, Catalogus van de Pamfletten-verzameling van de Koninklijke
Bibliotheek (Utrecht: HES, I978). It is remarkable that those poems thus far have gained little attention in scholarly research, see J. J. V. M. De Vet, 'The Image of William and Mary in Dutch Poetry', in The Age of William III and Mary II: Power, Politics and Patronage, I688-I702, ed. by R. P. Maccubin and M. Hamilton-Philips (Williamsburg, VA: The College of William and Mary in Virginia, 1989), p. 357 .

4 See De Vet, 'The Image of William and Mary', for some more examples and information about life and works of the poets.

5 Ibid., p. 356.

${ }^{6}$ About the Year of Disaster, see, for example, J. Israel, The Dutch Republic: Its Rise, Greatness 
and Fall, I477-I809 (Oxford: Clarendon Press, I995), pp. 796-806. The assumption has long been that the De Witt brothers were lynched by a hysterical crowd, but recently, Michel Reinders has argued otherwise, namely that their murder was a well-thought-out set-up by the involved citizens. See M. Reinders, "Burghers", Orangists and "Good Government": Popular Political Opposition during the "Year of Disaster" 1672 in Dutch Pamphlets', The Seventeenth Century 23:2 (2008a), 315-46. In his dissertation the argument is elaborated more extensively: M. Reinders, 'Printed Pandemonium: The Power of the Public and the Market for Popular Political Publications in the Early Modern Dutch Republic' (Ph. D. thesis, Erasmus Universiteit Rotterdam, 2008b), pp. $25 \mathrm{I}-73$.

7 About the stadholderate of William III, see, for example, Israel, The Dutch Republic, pp. 807-62.

8 Ibid., p. 8Io.

9 About the relationship between Amsterdam and William III, see also M. Hell, "'Schatkist van den Staet". Amsterdamse Regenten en de Hogere Overheid', in Geschiedenis van Amsterdam II-2. Zelfbewuste stadsstaat I $650-I 8 I 3_{3}$, ed. by W. Frijhoff and M. Prak (Amsterdam: SUN, 2005), pp. 199-207; and M. Prak, The Dutch Republic in the Seventeenth Century (Cambridge: Cambridge University Press, 2005), pp. 55-56.

${ }^{\text {Io }} \mathrm{His}$ poem, 'Engelands Vreugdegalm, op het Ontfangen van Zyn Koninklyke Hoogheid in Holland' can be found in Joachim Oudaens Poezy (Amsterdam: wed. P. Arentz and K. van der Sys, I7I2), vol. I, p. 270. The Amsterdam poet Thomas Arents (I652-I70I) seems to be an exception: he wrote both laudations and satirical verses on William III. See De Vet, 'The Image of William and Mary', p. 354; and Porteman and Smits-Veldt, Een Nieuw Vaderland, pp. 794, 798.

${ }^{\text {II }}$ Interestingly enough, poets seem to have been more critical in plays. See K. van der Haven, 'Voorzichtige Propaganda in Twee Amsterdamse Vredespelen', De Zeventiende Eeuw 25:I (2009), 39-52 (p. 40); K. van der Haven and T. Holzhey, 'Tieranny van Eigenbaat (1679). Staatsgezinde Propaganda in de Amsterdamse Schouwburg', De Zeventiende Eeuw 23:2 (2007), 245-67. A comparison between poems and plays regarding aspects of the stadholderate of William III deserves further research.

I2 Various articles have been written about William's religiosity. Authors do not agree to what extent William was a Calvinist or acted as one, but they do agree that many of William's actions did not meet the views of orthodox Calvinists. See, for example, F. Broeyer, 'William III and the Reformed Church of the Netherlands', in Redefining William III: The Impact of the King-Stadholder in International Context, ed. by E. Mijers and D. Onnekink (Aldershot: Ashgate, 2007), pp. Io9-23; J. Israel,
'William III and Toleration', in From Persecution to Toleration: The Glorious Revolution and Religion in England, ed. by O. P. Grell, J. I. Israel and N. Tyacke (Oxford: Clarendon Press, I99I), pp. I29-I70; or J. van den Berg, 'Religion and Politics in the Life of William and Mary', in Fabrics and Fabrications: The Myth and Making of William and Mary, ed. by P. Hoftijzer and C. C. Barfoot (Amsterdam/Atlanta: Rodopi, I990), pp. I7-40.

${ }^{13}$ See, for example, E. Bergin, 'Defending the True Faith: Religious Themes in Dutch Pamphlets on England, I688-1689', in War and Religion after Westphalia, I648-I713, ed. by D. Onnekink (Farnham: Ashgate, 2009), pp. 2I7-50.

${ }^{{ }^{14}} \mathrm{~T}$. Claydon, 'Protestantism, Universal Monarchy and Christendom in William's War Propaganda, I689-1697', in Mijers and Onnekink, Redefining William III, pp. I25-42; T. Claydon, William III and the Godly Revolution (Cambridge: Cambridge University Press, 1996). See also Bergin, 'Defending the True Faith'.

I5 For recent contributions to the continuous discussion about the interplay between commerce and ideology, see H. van Nierop, 'Profijt en propaganda. Nieuwsprenten en de verbeelding van het nieuws', in Romeyn de Hooghe. De Verbeelding van de Late Gouden Eeuw, ed. by H. van Nierop (Zwolle: Waanders, 2008), pp. 66-85; R. Harms, 'Thievery of Literature: Consequences of the Interaction between Politics and Commerce for the Form and Content of Pamphlets', in Pamphlets and Politics in the Dutch Republic, ed. by F. Deen, D. Onnekink and M. Reinders (Leiden, forthcoming 20I0).

${ }^{16} \mathrm{~J}$. Israel, Monarchy, Orangism, and Republicanism in the Later Dutch Golden Age (Amsterdam: Amsterdam Centre for Golden Age Studies, 2004), p. I3.

${ }^{17}$ De Vet, 'The Image of William and Mary', p. 354.

${ }^{\text {I8 }}$ For a short introduction to the life and work of Lescailje, see L. van Gemert, 'Katharina Lescailje (Amsterdam, 26 september I649-Amsterdam, 8 juni I7II). Schrijfster annex uitgeefster', in Met en zonder Lauwerkrans. Schrijvende Vrouwen uit de Vroegmoderne tijd I550-I850. Van Anna Bijns tot Elise van Calcar, ed. by R. Schenkeveld-van der Dussen and K. Porteman (Amsterdam: Amsterdam University Press, I99I), pp. 396-402.

${ }^{19} \mathrm{~K}$. Lescailje, Tooneel- en Mengelpoëzy, 3 vols (Amsterdam: Erfgen. Lescailje en Dirk Rank, I73I). The first two volumes of the Tooneel- en Mengelpoëzy are available online at < http:// digbijzcoll.library.uu.nl/> (search 'Lescailje'), 22 January 2010.

${ }^{20}$ For some preliminary remarks on the political poetry of Lescailje, see N. Geerdink, 'Katharina Lescailje: Another Sappho', <www.womenwriters.nl/index. php/Katharina_Lescailje_(I649-I7II):_another_ Sappho>, 22 January 2010. 
${ }^{21}$ See, for example, the huge number of nuptial poems Lescailje wrote. I have argued that their number was related to her need for earnings. See N. Geerdink, 'The Appropriation of the Genre of Nuptial Poetry by Katharina Lescailje (I649-I7II)', in Women Writing Back / Writing Women Back, ed. by S. van Dijk, A. Montoya and A. Gilleir. Intersections. Interdisciplinary Studies in Early Modern Culture (Leiden: Brill, forthcoming 20I0).

22 Thomas Arents (see note II) was a member of the association. For the political ideas of Nil members see Van der Haven and Holzhey, 'Tieranny van Eigenbaat (I679)', pp. 254-55.

${ }^{23}$ For a list of theatre directors see C. N. Wybrands, Het Amsterdamsche Tooneel van ${ }_{16} 6_{17-1772}$ (Utrecht: J. L. Beijers, I873), pp. 227-30.

${ }^{24}$ See Porteman and Smits-Veldt, Een Nieuw Vaderland, pp. 796-98.

${ }^{25}$ It is almost impossible to say something about Lescailje's ideology, since the only sources for her ideological stance are her poems. It is unlikely that poetry in itself reveals the ideology of an author; see, for example, H. van Nierop, 'Profijt en propaganda', pp. $82-83$.

${ }^{26}$ Porteman and Smits-Veldt, Een Nieuw Vaderland, p. 788. For an overview of the poems written in support of De Witt in 1672 , see A. Munt, 'The Impact of the Rampjaar on Dutch Golden Age Culture', Dutch Crossing 2I:I (I997), 3-5I (pp. 6I2). See also Reinders, 'Printed Pandemonium', pp. $273-79$.

${ }^{27}$ See Reinders, "Burghers", Orangists and "Good Government”, p. 332.

${ }^{28}$ Het Swart Toneel-gordyn, Opgeschoven voor de Heeren Gebroederen Cornelis en Joan de Wit (s. l., s.n., 1676), p. 26. The pamphlet is recorded in Knuttel, Catalogus, catalogue no. II4Io. Swart Toneel-gordyn was reprinted and enlarged several times in 1676 and the following years. The two poems by Lescailje were also republished in Lescailje, Tooneel- en Mengelpoëzy, vol. I, pp. 29-30.

${ }^{29}$ For the Gelderland affair, see, for example, Israel, The Dutch Republic, pp. 8I 5-I8.

${ }^{30}$ Lescailje, Tooneel- en Mengelpoëzy, vol. I, pp. $3 \mathrm{I}-35$ and $36-40$.

${ }^{3}$ Porteman and Smits-Veldt, Een Nieuw Vaderland, pp. 790-9I.

32 See M. Spies, “"Vrijheid, Vrijheid": Poëzie als Propaganda, 1565-1665', in Vrijheid. Een Geschiedenis van de Vijftiende tot de Twintigste eeuw, ed. by E. O. G. Haitsma Mulier and W. R. E. Velema (Amsterdam: Amsterdam University Press, I999), pp. 7I-98 (pp. 93-94); and M. Spies, 'Verbeeldingen van Vrijheid: David en Mozes, Burgerhart en Bato, Brutus en Cato', De Zeventiende Eeuw I0: I (1994), I4I-58.

33 Ever since the Dutch Revolt, the concept of 'freedom' has been related to the Dutch Republic. Indeed, 'freedom' was a dominant concept in Dutch politics. Its meaning, however, was manifold. Although everyone agreed that the Republic was a free state, and its connotation was always positive, its specific meaning depended on the political discourse, political events, and the background and position of the person using the term. The 'True Freedom' was appropriated by the States-party from I650. See, for example, Haitsma Mulier and Velema, Vrijheid and J. D. M. Cornelissen, Johan de Witt en de Vrijheid (Nijmegen/Utrecht: Dekker \& Van de Vegt, I945), pp. 8-9.

${ }^{34}$ R. Fruin, De Oorlog van 1672 (Groningen: WoltersNoordhoff, I972), p. 257.

35 See, for example, J. T. Rosenthal, 'The King's "Wicked Advisers" and Medieval Baronial Rebellions', Political Science Quarterly 82:4 (I967), 595-618. I owe this reference to Jan Hartman.

${ }^{36}$ A strong anti-monarchical sentiment was part of republican political thought, which was also dominant among later Orangists, see Israel, Monarchy, pp. 6-8.

37 This translation, and all the further translations in this article, are made by myself.

${ }^{3}$ See note 33 .

${ }^{39}$ K. Lescailje, 'Op het Vertrek van den Doorluchtigsten Vorst zyn Hoogheid Wilhem den Derden, Prince van Oranje, Grave van Nassouw, enz: Stadhouder, Kapiteyn en Admiraal Generaal der Vereenigde Nederlanden, enz.' (s.l., s.n., [1672]). The poem was republished in Lescailje, Tooneel- en Mengelpoëzy, vol. I, pp. 4I-43.

$4^{\circ} \mathrm{K}$. Lescailje, 'Hollants Zege ter Zee, onder 't Beleid van den Manhaften Held Michiel de Ruiter, Ridder, L. Ammiraal generaal, \&c. \&c. tegens de twee Koningklijke Vlooten van Vrankrijk en Engelant, den VII.den en XIV.den van Zomermaant, I673, Kloekmoedelyk Bevochten' (Amsterdam: J. Lescaille, I673). The poem was republished in Lescailje, Tooneel- en Mengelpoëzy, vol. I, pp. 50-54.

${ }^{\mathrm{I}}$ ' $\mathrm{Op}$ het Verlaaten van Uitrecht' was published in Lescailje, Tooneel- en Mengelpoëzy, vol. I, pp. 4446; 'Woerdens Wellekomst aan zyn Koningklyke Hoogheid, den Heere Prince van Oranje langgewenschten Stadhouder, en Kapitein generaal der Vereenigde Nederlanden' was published in Tooneel-en Mengelpoëzy, vol. I, pp. 47-49.

${ }^{42}$ The only reason to call William royal at that time would have been because of his ancestry. As the son of Mary Stuart (I63I-I660), the daughter of the English King Charles I, he did have royal blood. It is also possible, however, that this form of address was added only in I73I, by the editors of Lescailje's collected works.

${ }^{43}$ See, for example, E. Mijers and D. Onnekink, 'Introduction', in Redefining William III, p. I.

44 'Vreêverbond' (I674) in Lescailje, Tooneel- en Mengelpoëzy, vol. I, pp. I7-20; and 'Zegepralende 
Vrede' (I678) in Tooneel- en Mengelpoëzy, vol. I, pp. 2I-26. The poem from 1678 was also published separately, see K. Lescailje, De Zeegepraalende Vreede (Amsterdam: J. Lescaille, I678), c.f. Knuttel, Catalogus, catalogue no. II 599.

45 Porteman and Smits-Veldt, Een Nieuw Vaderland, p. 795 .

${ }^{46} \mathrm{~K}$. van der Haven, Achter de Schermen van het Stadstoneel. Theaterbedrijf en Toneelpolemiek in Amsterdam en Hamburg $1675-1750$ (Zutphen: Waanders, 2008), pp. 259-60, points to the decrease in the number of plays being performed in the Amsterdam theatre from 1687 onwards. This must have been felt by Lescailje, who was the regular printer for the theatre.

47 Lescailje, Tooneel-en Mengelpoëzy, vol. I, p. 27.

$4^{8}$ Pamphlets about the crossing can be found in Knuttel, Catalogus.

${ }^{49}$ Lescailje, Tooneel- en Mengelpoëzy, vol. I, p. 28.

${ }^{50}$ Lescailje's poem was not represented in booklets such as De Konincklycke Triumphe Vertoonende Alle de Eerpoorten [... Opgerecht in 's Gravenhage I69I ter Eere van Willem de III (Den Haag: Barent Beeck, I69I). Again, more poems can be found in Knuttel, Catalogus. Lescailje's poem was printed, however, in the collection Nieuwe Verzameling van Nederduitsche Mengeldichten (Amsterdam: W. Barentsz, I727), p. 56, which makes it likely that the poem was circulated in the year of writing.

${ }^{5}$ The collection can be found in Knuttel, Catalogus, catalogue no. I4180. Opkomst, Geboorte, Leven en Dood van Maria Stuart, Koninginne van GrootBrittanien, Vrankryk en Yerland (Amsterdam: J. ten Hoorn, I695). The elegy was also published separately, see P. A. Tiele, Catalogus der Bibliotheek van Joannes Thysius (Leiden: Brill, 1879), catalogue no. 9362.

$5^{2}$ Lescailje, Tooneel- en Mengelpoëzy, vol. II, p. 382.

${ }_{53}$ Between 1688 and 1702 , Lescailje also wrote one poem not explicitly in honour of William but praising the consequences of his actions, 'Daphnis Harderszang op de Vrede' (Tooneel-en Mengelpoëzy, vol. I, pp. 3-8), which celebrated the Peace of
Rijswijk of I697. Remarkably, both God and William were completely absent from this poem. 'Daphnis Harderszang' was an allegorical pastoral, and therefore a different framework from the religious one accounts for the absence of praise for William. This genre was often used to cover politically delicate matters, see Van der Haven, 'Voorzichtige propaganda'.

${ }^{54}$ It is remarkable that Lescailje's elegy for Mary Stuart - the only poem she wrote solely in honour of William's wife - was less religious in tone than the poems written for William. Elsewhere I have argued that the lack of a dominant religious framework in this poem, especially in comparison with poems by other female elegists, was caused by the fact that Lescailje wanted to present herself as an author with masculine attributes, rather than as a typical female author. From the perspective of my current argument, however, another explanation also comes to mind: it is possible that the image of Mary Stuart, who was known as 'Good Queen Mary' and who was famous for her care of people, fitted, more than William, in a patriotic discourse. This poem, maybe, did not need the religious elements to justify its praise. See N. Geerdink, "Rouw om een "cieraat grooter vrouwen". Lijkdichten bij de Dood van Maria Stuart (I695) door Mannen en Vrouwen', Historica, 32:I (2009), 3-5.

55 For example the elegies for the mayors Hendrik Hooft (I678), Gillis Valckenier (I680), and Jan Six (I700), in Lescailje, Tooneel- en Mengelpoëzy, vol. II, pp. 329-30, 33I and 379-8I.

${ }^{56}$ Ibid., vol. I, p. I6.

57 Israel, The Dutch Republic, pp. 968-69.

${ }^{8}$ See the poems in Lescailje, Tooneel- en Mengelpoëzy, vol. I, pp. 9-I5. For God's praise in Protestant war discourse in this period, see D. Haks, 'Propaganda from the Pulpit?', in Anthonie Heinsius and the Dutch Republic: Politics, War, Finance, ed. by J.A. F. de Jongste and J. Veenendaal Jr (The Hague: ING, 2002), pp. 89-III.

\section{Notes on contributor}

Nina Geerdink is a $\mathrm{PhD}$ candidate in the Department of Dutch Literature at VU University Amsterdam. Her research concerns early modern literature and she is working on a dissertation about authorial self-representation and the social anchoring of seventeenth-century Dutch authorship.

Correspondence to Nina Geerdink, VU University Amsterdam, Faculteit der Letteren, Afd. Literatuur \& Cultuur, De Boelelaan II05, NL-Io8I HV, Amsterdam, The Netherlands. Email: n.geerdink@let.vu.nl 